\title{
Synthesis of Molecular Synthons for Porphyrinpolymers
}

\author{
Tatiana A. Ageeva, ${ }^{\mathrm{a}, \mathrm{b}}$ Sergey A. Syrbu, ${ }^{\mathrm{a}}$ and Oscar I. Koifman ${ }^{\mathrm{a}, \mathrm{b}}$ \\ avanovo State University of Chemistry and Technology, Ivanovo, 153000, Russia \\ ${ }^{b}$ Institute of the Solution Chemistry of Russian Academy of Sciences, Ivanovo, 153045, Russia ${ }^{\circledR}$ Corresponding author \\ E-mail:tageeva@isuct.ru
}

\begin{abstract}
Peculiarities of the unique structure of porphyrins, possibilities of their peripheral functionalization, ability of metal complexes to extracoordination allow to use them for inclusion in porphyrin-polymer systems in order to endow them with specific properties, determined by tetrapyrrole macrocyclic compounds and their complexes. Porphyrins and their analogues being immobilised on a polymer carrier not only preserve their useful properties, but even strengthen them due to co-operative interactions in polymer chains, separation of active centres, increase of stability of tetrapyrrole fragments This review systematise methods of synthesis of meso-phenyl substituted porphyrins which can be used for fastening on a polymer-carrier. The general approaches to functionalization of porphyrin monomers and their immobilization on synthetic polymers by macromolecular reactions and copolymerization are considered. Strategy of porphyrin-polymer syntheses is based on the previoiusly obtained regularities of mutual influence of the structure of tetrapyrrolic macroheterocycles and polymer-carriers and their ability to self-organization.
\end{abstract}

Keywords: Porphyrins, porphyrin-polymers, synthesis, monomers, molecular synthons, immobilization, copolymerization.

Агеева Татьяна Арсеньевна, родилась в 1953 г. в г. Шуе Ивановской области. В 1975-1979 г2. обучалась в заочной аспирантуре Ивановского химико-технологического института (ИХТИ) под руководством Б. Д. Березина и в 1979 г. защитила кандидатскую диссертаиию на тему “ Сравнительные исследования кинетики и термодинамики образования стабильных и лабильных комплексов порфиринов". С 1975 г. по 1996 г2. работала соответственно на кафедре органической химии ИХТИ и в Отделе химии порфиринов Института химии растворов РАН, возглавляемых Б. Д. Березиным. С 1996 г. работает доиентом в Ивановском государственном химико-технологическом университете и занимается исследованиями в области порфиринсодержащих полимеров $и$ новых функииональных материалов.

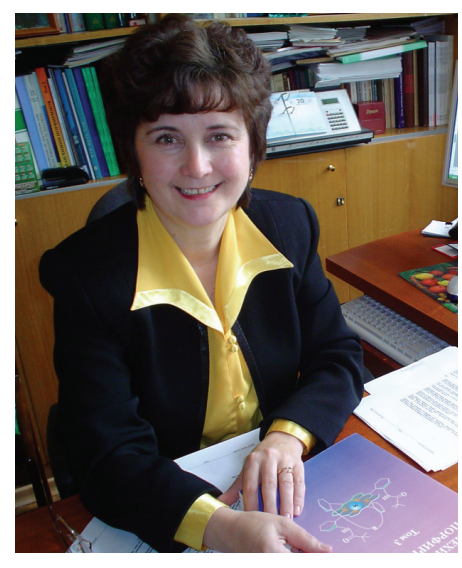

Dr. Tatiana Arsen'evna Ageeva was born in 1953 in Shuya of Ivanovo region. During 19751979 she was a post-graduate student of Ivanovo Institute of Chemistry and Technology under the supervision of Prof. B.D. Berezin and in 1979 received the Degree "Candidate of Chemical Sciences" (PhD) for the dissertation "Comparative investigation of kinetics and thermodynamics of the formation of stable and labile porphyrin complexes". Since 1975 up to 1996 she worked in the Department of Organic Chemistry at Ivanovo Institute of Chemistry and Technology and in the Department of Porphyrin Chemistry at the Institute of Solution Chemistry of Russian Academy of Sciences, headed by Prof. B.D. Berezin. Since 1996 she is associate professor at Ivanovo State University of Chemistry and Technology and currently conducts the research in the field of porphyrin containing polymers and new functional materials.
Сырбу Сергей Александрович, родился в 1961 г. в г. Иваново. В 1983-1986 г2. обучался в очной аспирантуре Ивановского химикотехнологического института (ИХТИ) под руководством Б.Д. Березина и в 1987 г. защитил кандидатскую диссертащию на тему "Разработка новых методов синтеза и химическая модификация оксизамещенных тетрафенилпорфинов". С 1987 г. по 1995 работал на кафедре органической химии ИХТИ, возглавляемой Б. Д. Березиным. В 2008 2. защчитил докторскую диссертациию на тему "Синтез и реакичи мезофенилзамещенных порфиринов”. С 1995 г. работает в Ивановском государственном химико-технологическом университете (ИГХТУ) и занимается исследованиями в области синтеза и модификации порфиринов.

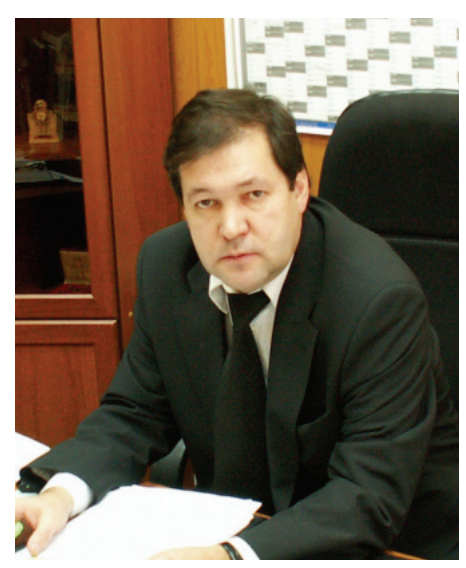

Dr. Sergey Aleksandrovich Syrbu was born in 1961 in Ivanovo. In 1983-1986 he was a postgraduate student at Ivanovo Institute of Chemistry and Technology under the supervision of Prof. B.D. Berezin and in 1979 received the Degree "Candidate of Chemical Sciences" (PhD) for the dissertation "Elaboration of the new synthetic methods and the chemical modification of oxy-substituted tetraphenylporphyrins". During 1987-1995 he worked in the Department of Organic Chemistry at Ivanovo Institute of Chemistry and Technology, headed by Prof. B.D. Berezin. In 2008 he defended the dissertation "Synthesis and reactions of meso-phenylsubstituted porphyrins" and received the degree "Doctor of Chemical Sciences". Since 1995 he is associate professor at Ivanovo State University of Chemistry and Technology; his scientific interests lies in the field of synthesis and modifications of porphyrins. 


\title{
Синтез молекулярных синтонов Аля порфиринполимеров
}

\author{
Т.А. Агеева, ${ }^{a, b @ ~ C . А . ~ С ы р б у, ~}{ }^{a}$ О.И. Койфрман ${ }^{a, b}$

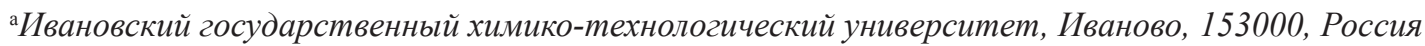 \\ ${ }^{\mathrm{b}}$ Институт химии растворов РАН, Иваново, 153045, Россия \\ @E-mail: tageeva@isuct.ru
}

\begin{abstract}
Обзор посвящён методам направленного синтеза тетрапиррольных макрогетероцикличесих соединений на основе мезо-фенилзамещенных порфиринов, которые могут быть использованы для включения в полимерную систему. Рассматриваются общие подходы к функционализации периферии порфиринового макрогетероцикла и методы иммобилизации на синтетических полимерах с использованием макромолекулярных реакций и сополимеризации.
\end{abstract}

Ключевые слова: Порфирины, порфиринполимеры, синтез, мономеры, молекулярные синтоны, иммобилизация, сополимеризация.

Исследования в области синтетической, физической и координационной химии, проводимые в течение сорока лет под руководством Б.Д. Березина, ${ }^{[1-4]}$ прежде всего, были направлены на создание моделей природных порфиринов и раскрытия механизмов их функционирования в нативных процессах, таких как растительный и бактериальный фотосинтез, дыхание, ферментативный катализ, сульфит- и нитроредукция, метаногенез и др. Накопление данных об особенностях поведения и специфики свойств этих соединений позволило найти области их применения и, в первую очередь, биопорфиринов. ${ }^{[5]}$ Во всех биологически важных системах фотосинтеза и дыхания порфирин не является изолированной единицей, а функционирует только в составе сложных молекулярных комплексов с высокомолекулярными и малыми молекулами. Строго определенная комбинация иона металла, макрогетероциклического лиганда и специфического окружения биополимера является определяющим фактором для проявления биологической активности и селективности этих соединений в живых организмах. Малейшие изменения, происходящие с центральным атомом металла, структурой порфирина или макромолекулярным окружением, приводят к возникновению разнообразных биохимических реакций. ${ }^{[4]}$ В связи с этим получение моделей природных супер- и супрамолекулярных порфиринсодержащих систем, подобных природным, вызывает огромный интерес.

Закрепление порфирина на биополимере в природных системах может осуществляться одновременно как за счет ковалентного связывания периферических функциональных групп порфирина, так и за счет координационного взаимодействия центрального иона металла c макромолекулой полимера. ${ }^{[6]}$ Используя биомиметический подход к конструированию синтетических порфирин-полимерных систем, в основу методологии синтеза обычно закладывают только один тип взаимодействия тетрапиррольного макрогетероциклического соединения с макромолекулой полимера. ${ }^{[7]}$

Особенности уникальной структуры порфиринов, возможность функционализации периферии макрогетероцикла, склонность металлопорфиринов к экстрако- ординации позволяют использовать эти соединения для включения в порфирин-полимерные системы с целью придания им специфических свойств, определяемых порфиринами. Порфирины и их аналоги при закреплении на полимере-носителе не только сохраняют свои специфические свойства, но и усиливают их за счет кооперативных взаимодействий в полимерных цепях, разделения активных центров, повышения стабильности тетрапиррольного фрагмента. Таким образом, тетрапиррольные макрогетероциклические соединения являются уникальными молекулярными синтонами для создания порфиринполимеров.

Порфирин может быть включен в полимерную систему, как часть основной макромолекулярной цепи, так и закреплен в боковой цепи. Сегодня известно большое количество порфиринполимерных систем различной структуры. В зависимости от типа связывания, взаимного расположения составляющих системы их обычно подразделяют на полипорфирины, иммобилизованные порфирины и координационные полимеры. [7] Каждая из этих групп порфиринполимеров представляет определенный интерес и уже нашла свои области применения. Однако, обращаясь к природным системам, следует остановиться на иммобилизованных порфиринах, или, как их еще принято называть, порфирин-полимерных иммобилизатах (ППИ), ${ }^{[8]}$ представляющих наиболее многочисленную группу. ППИ содержат в боковой цепи полимера тетрапиррольный макрогетероцикл, соединенный с ней посредством ионной, ковалентной или координационной связи и разделенный с основной полимерной цепью определенным спейсером. Длина спейсера и количество мостиков, связывающих тетрапиррольный макрогетероцикл c полимером-носителем, определяют доступность макрогетероцикла реагентам, его подвижность и реакционную способность. Структура иммобилизованных порфиринов, которые должны быть сконструированы и соединены между собой оптимальным образом, представлена на Рисунке 1.

К полимеру-носителю (1) должны быть присоединены, по крайней мере, два типа групп: порфирин вместе со связующим мостиком - спейсером (А) и функ- 


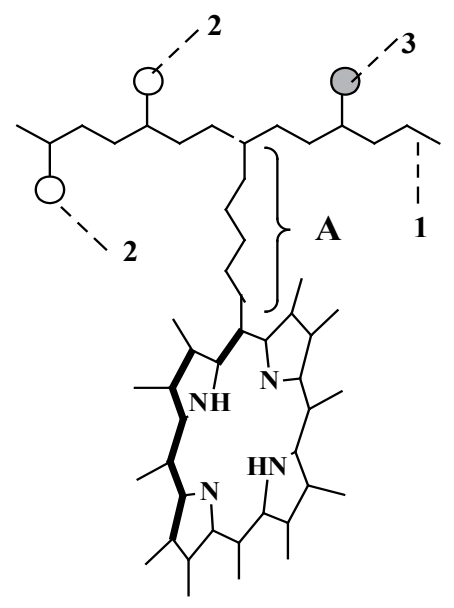

Рисунок 1. Модель порфирин-полимерного иммобилизата.

циональные группы (2), придающие гидрофильность или гидрофобность системе и обеспечивающие ей растворимость в той или иной среде. Кроме того, в зависимости от области применения полимерсвязанных порфиринов к макромолекуле полимера может быть присоединен третий тип функциональных групп-лигандов (3), выполняющих вспомогательную функцию и обеспечивающих целевой транспорт субстратов в каталитических процессах, узнавание клеток-мишеней в биологических системах. В связи с этим полимер-носитель порфирина, определяющий молекулярные свойства системы, должен иметь активные функциональные группы, обеспечивающие присоединение функционализированных порфиринов и группы, придающие необходимую растворимость системе.

Молекулярные синтоны, позволяющие конструировать ППИ, отвечающие представленной модели, могут быть как иммобилизантами, так и мономерами, в зависимости от того какой метод синтеза будет положен в основу их получения. В настоящее время существуют два метода создания таких систем: макромолекулярный синтез, основанный на модификации традиционных полимеров или специально синтезированных в качестве полимеров-носителей, ${ }^{[9]}$ и метод сополимеризации порфириновых мономеров с другими мономерами непорфириновой природы. Общие принципы иммобилизации порфиринов на полимеры-носители аналогичны описанным для других соединений. ${ }^{[10,11]}$

В качестве иммобилизантов могут быть выбраны порфирины, имеющие активные функциональные группы, обеспечивающие иммобилизацию функционализированных порфиринов. Все природные порфирины в своей структуре содержат необходимые элементы, позволяющие им тем или иным образом включаться в биополимерные комплексы, и, следовательно, их можно рассматривать как удобные молекулярные синтоны для синтеза новых порфиринполимерных систем. Хлорофилл $a \mathbf{1}\left(\mathrm{R}=\mathrm{CH}_{3}\right)$ имеет в положении 2 винильную группу, способную участвовать в реакциях сополимеризации с мономерами непорфириновой природы, две сложноэфирные группы: в положении 7 - алкилированная фитольным остатком пропионильная и в циклопентеновом кольце - метоксикарбонильная, представляющие собой скрытые активные функциональные группы, которые могут быть использованы для ковалентной или ионной иммобилизации его на полимерыносители. Хлорофилл $b \mathbf{1}(\mathrm{R}=\mathrm{CHO})$ имеет в положении 3 формильную группу, которая также может быть использована для иммобилизации его на полимерыносители, например на поливиниловый спирт. Винильные группы гемина 2 (в положениях 2 и 4) также способны участвовать в реакциях сополимеризации, а пропионильные группы (в положениях 6 и 7) представляют активные центры для ковалентной иммобилизации его на полимеры-носители.

Кроме того активным реакционным центром природных порфиринов является центральный атом металла, находящийся в координационом центре тетрапиррольного макрогетероцикла $\left(\mathrm{Mg}^{\mathrm{II}}\right.$ - в хлорофиллах и $\mathrm{Fe}^{\mathrm{III}}$ - в гемине), который способен участвовать в образовании координационных полимеров, а также координационносвязанных полимерных и супрамолекулярных структур.

Среди синтетических тетрапиррольных макрогетероциклических соединений привлекательны порфирины, содержащие в мезо-положениях арильные заместители, которые можно подвергать разнообразным химическим превращениям. В настоящее время для моделирования свойств природных порфиринов используются в основном их синтетические аналоги - мезотетрафенилпорфирины 3 (ТРР), легко получаемые конденсацией пиррола с бензальдегидами. Однако в ряде случаев они не удобны, так как в отличие от природных порфиринов не имеют алкильных или псевдоалкильных заместителей в $\beta$-положениях порфиринового цикла, в то время как мезо-положения, напротив, замещены. Достаточно доступные октаалкилпорфирины 4 не могут быть

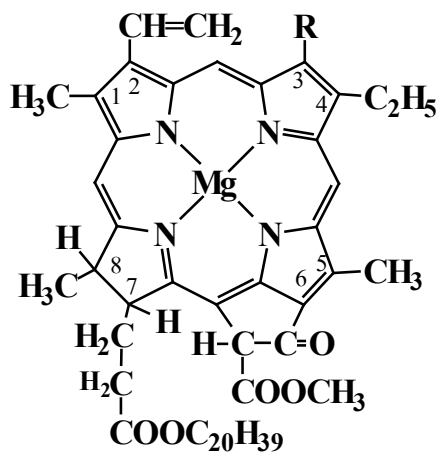

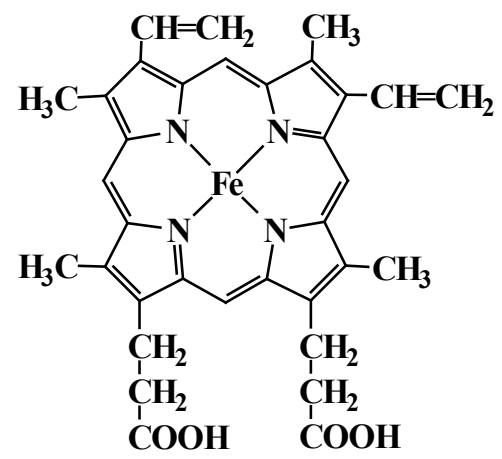




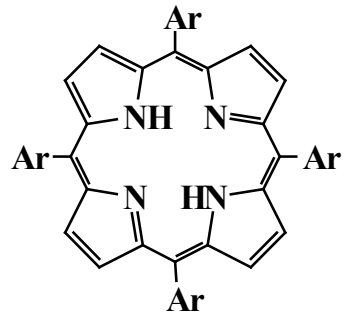

3

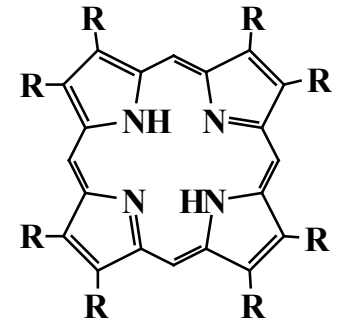

4

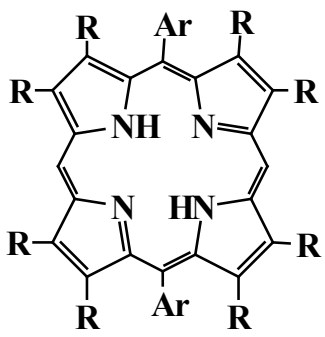

5

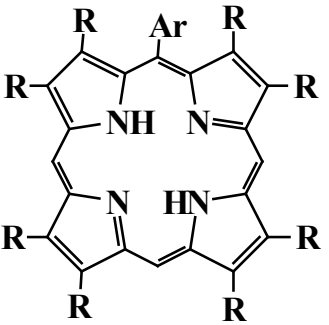

6 использованы в качестве иммобилизантов, т. к. не имеют активных групп, которые можно легко изменить для придания им необходимой реакционной способности. Кроме того, обычно используемая симметричная система заместителей в порфиринах ограничивает их применение в реакциях получения полимеров. Наличие четырех одинаковых заместителей в макроцикле приводит, как правило, к образованию сильно разветвленных или сшитых полимерных структур. Поэтому целесообразно использовать порфирины с асимметричной системой заместителей. Для этих целей, равно как и для синтеза порфиринсодержащих полимеров, наиболее удобными соединениями являются моно- и дизамещенные порфирины. Поэтому наибольший интерес вызывают порфирины, совмещающиедостоинствамезо-тетрафенилпорфиринов и октаалкилпорфиринов, такие, например, как 5,15-диарилокталкилпорфирины 5 и 5-арилокталкилпорфирины 6. Такие порфирины получаются в основном путем конденсации $\alpha$-незамещенных линейных производных пирролов с бензальдегидами. ${ }^{[12,13]}$

Следует заметить, что функционализированные 5,15-диарилокталкилпорфирины 5, при закреплении на полимере-носителе выполняют роль сшивающего агента и в конечном итоге приводят к получению структурированных материалов, в которых тетрапиррольные макрогетероциклы в значительной степени экранированы макромолекулярным окружением и степень подвижности их снижена. В связи с этим в качестве иммобилизантов наибольший интерес представляют монозамещенные порфирины. Общие подходы к синтезу мезо-фенилпорфиринов обобщены в обзоре. ${ }^{[12]}$

Направленная функционализация порфиринов определяется выбором полимера-носителя, что в итоге является определяющим фактором для успешного закрепления порфирина или его металлокомплекса. Исходный полимер-носитель выбирается или конструируется с заранее заданными свойствами (определенной растворимостью, заданной молекулярной массой и молекулярно-массовым распределением). С этой целью можно использовать известные гомополимеры такие как поливиниловый спирт, полиметакриловая кислота, поливиниламин, эфиры целлюлозы и др. Однако, высокая концентрация активных функциональных групп в полимерной цепи не является достоинством полимеровносителей. Число порфириновых фрагментов, приходящихся на одно элементарное звено полимера, может меняться в широких пределах, но оно всегда значительно ниже 1, так как в силу больших размеров молекул порфиринов по сравнению с элементарным звеном полимера стерически невозможно получить высокозамещенные полимерсвязанные порфирины. Кроме того в таких системах фрагменты порфирина будут очень сильно экранированы, и результативность их последующего использования будет мала. Поэтому наиболее перспективно использовать в качестве полимера-носителя сополимеры, в которых мономерные звенья, содержащие активные функциональные группы, чередуются с химически неактивными (например, стиролом или метилметакрилатом). Такие сополимеры легко получаются сополимеризацией различных мономеров, отдельные из которых имеют необходимые функциональные группы. Количество этих групп можно регулировать условиями синтеза. В образующихся сополимерах реакционноспособные группы регулярно или случайно распределяются по длине полимера и определяют место иммобилизации порфирина. Природа активной группы в сополимере определяет структуру и природу функциональных групп на периферии порфирина.

В качестве иммобилизантов чаще всего используются порфирины, имеющие в качестве активных групп $-\mathrm{OH},-\mathrm{NH}_{2},-\mathrm{COOH},-\mathrm{COH}$.

мезо-Тетраоксифенилпорфирины образуются в реакциях конденсации пиррола с оксибензальдегидами с низкими выходами и большим количеством трудноотделимых примесей. Однако хорошие результаты получаются при проведении смешано-альдегидной конденсации оксибензальдегида вместе с другими бензальдегидами и пирролом, при этом образуются монооксифенилтрифенилпорфины с относительно высоким выходом (около 20\%). ${ }^{[14,15]}$

Защита оксигруппы в оксибензальдегидах ацилированием $^{[16]}$ приводит к существенному увеличению выхода порфиринов, из которых путем гидролиза в щелочной среде можно достаточно легко получить требуемые мезо-оксифенилпорфирины. Однако наиболее перспективным методом синтеза мезооксифенилпорфиринов в настоящее время является деметилирование легко доступных мезо-метоксифенилпорфиринов (Схема 1).

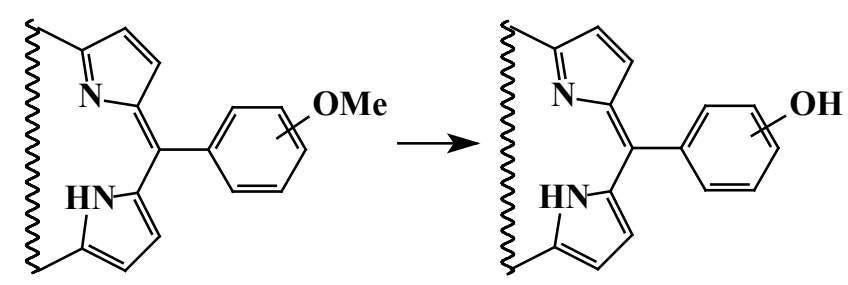

Схема 1. 

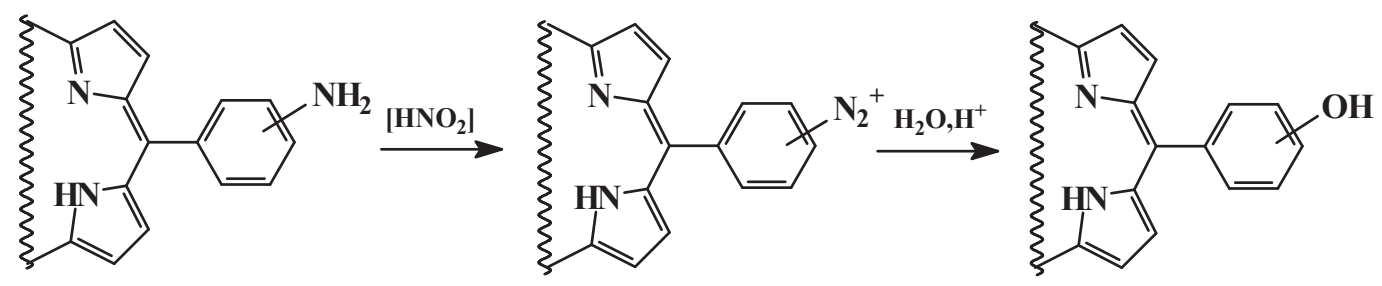

Схема 2.

Проведение гидролиза метоксифенилпорфиринов наиболее общим методом (48\%-ной бромистоводородной кислотой) показало, ${ }^{[17]}$ что этот метод мало эффективен, ввиду его длительности и неполноты превращения.

Хорошие результаты получаются при использовании в качестве деметилирующих агентов гидрохлоридов пиридина или анилина при кипении. ${ }^{[17]}$ Однако этот метод применим лишь при синтезе наиболее устойчивых мета- и пара-оксизамещенных тетрафенилпорфиринов, в то время как их орто-замещенные производные, а также монооксифенил- и диоксифенилпорфирины подвергаются значительной деструкции в условиях данной реакции.

Более подходящим деметилирующим агентом для синтеза оксифенилпорфиринов является 60\%-ная бромистоводородная кислота (кипячение в инертной атмосфере), использование которой позволяет существенно повысить их выход. ${ }^{[17]}$

В настоящее время для гидролиза метоксифенилпорфиринов используется мягкий деметилирующий агент - трибромид бора в хлористом метилене при $-20^{\circ} \mathrm{C}$ в инертной атмосфере. ${ }^{[18,19]}$ Однако было показано, ${ }^{[20]}$ что реакцию деметилирования можно без снижения выхода продукта проводить при комнатной температуре на воздухе в хлороформе.
Кроме того, оксифенилпорфирины можно получить гидролизом солей диазония мезо-фенилпорфиринов, которые в свою очередь получают диазотированием соответствующих мезо-аминофенилпорфиринов ${ }^{[21,22]}$ (Схема 2).

Гидроксильная группа в тетрапиррольном макрогетероцикле является активным центром закрепления его на полимеры-носители, особенно на полимерные кислоты. Моногидроксизамещенные порфирины приводят к образованию линейных полимеров с достаточно подвижным и доступным для реагентов макрогетероциклом.

При проведении процесса иммобилизации порфиринов следует иметь в виду, что жесткие условия реакции могут привести к термоокислительной деструкции полимера. Порфирины и их металлокомплексы, особенно природные, тоже чувствительны к внешним воздействиям среды. Поэтому поиск мягких условий иммобилизации, исключающих побочные процессы, представляет особый интерес в разработке методов синтеза порфиринполимеров.

В связи с этим предложены мягкие условия иммобилизации порфиринов, на гидроксилсодержащий полимер-носитель, подвергнутый эпоксиактивации.. ${ }^{[23,24]}$ Суть метода заключается в том, что реакционноспособ-<smiles>CCC(CC(COCC1CO1)CC(C)c1ccccc1)c1ccccc1</smiles>

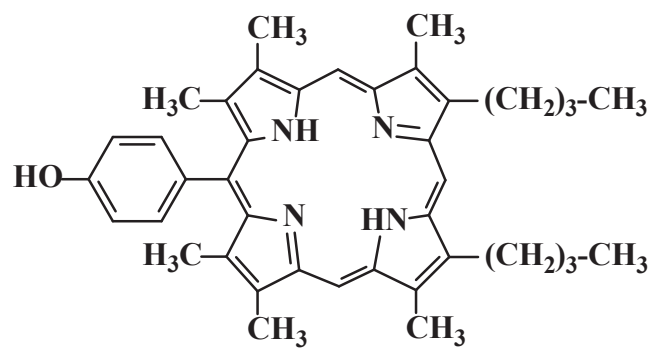<smiles>CCC(CC(COCC(O)COC(C)C)CC(C)c1ccccc1)c1ccccc1</smiles>

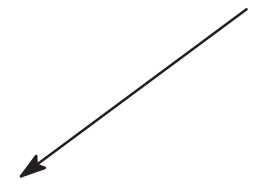

Схема 3.

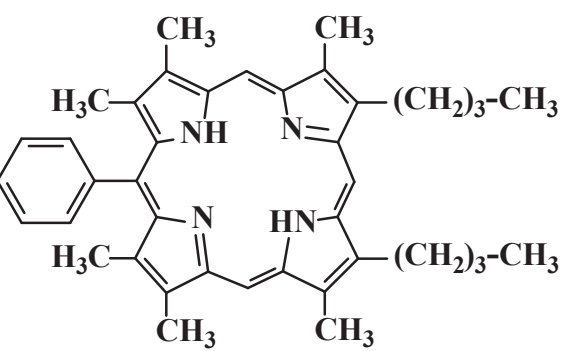


ные гидроксильные группы полимера при обработке эпихлоргидрином или другим реагентом, имеющим эпокси-группу, превращаются в высокоактивный эпоксидированный полимер, который легко вступает в реакции с соединениями, имеющими подвижный атом водорода в функциональной группе (-OH, $\left.-\mathrm{NH}_{2},-\mathrm{COOH}\right)$. Взаимодействие порфирина с активированным таким образом полимером (Схема 3) протекает при комнатной температуре и тем самым сохраняет молекулярные и физико-механические свойства полимерной системы.

Этот метод позволяет закрепить на полимерной матрице различные по структуре порфирины. Лучшие результаты в иммобилизации порфирина получаются при использовании полимера-носителя с редко распределенными по макромолекуле полимера гидроксильными группами. Таким носителем может быть сополимер винилового или аллилового спирта со стиролом, изменение состава которого позволяет изменять растворимость полимера в различных средах и регулировать количество присоединенного порфирина в полимере.

Важной реакцией в получении молекулярных синтонов порфиринполимеров является реакция алкилирования оксифенилпорфиринов галогеналканами. Она позволяет одностадийно из одного предшественника получать порфирины, обладающие разнообразными физико-химическими свойствами или имеющими активные группы на периферии молекулы. Эти актив- ные группы могут взаимодействовать с координационным центром порфиринового макрогетероцикла, образуя супрамолекулярные комплексы, или служить центром взаимодействия молекулы с различными субстратами.

Алкилирование оксифенилпорфинов проводиться, в основном, первичными галогеналканами в диметилформамиде в присутствии в качестве основного агента карбоната калия при комнатной температуре для лабильных оксифенилпорфиринов ${ }^{[25,26]}$ или при кипении для устойчивых производных тетрафенилпорфина, что значительно уменьшает время взаимодействия. ${ }^{[27]}$ Выход алкоксипроизводных порфиринов в среднем составляет 80-95\%. Спирты в качестве алкилирующих агентов практически не используются для проведения данной реакции, так как в них плохо растворимы как исходные порфирины, так и продукты реакции.

Этот метод позволяет синтезировать различные алкоксизамещенные порфирины хорошо растворимые в неполярных органических растворителях, ${ }^{[26,27]}$ а также тетра(карбэтоксиметиленоксифенил)порфирины 7 при гидролизе которых образуются растворимые в щелочных растворах тетра(карбоксиметиленоксифенил)порфирины $8^{[28]}$ (Схема 4).

Порфирины, содержащие карбоксильные группы, подобно природным порфиринам крови являются удобными синтонами порфирин-полимерных иммо-

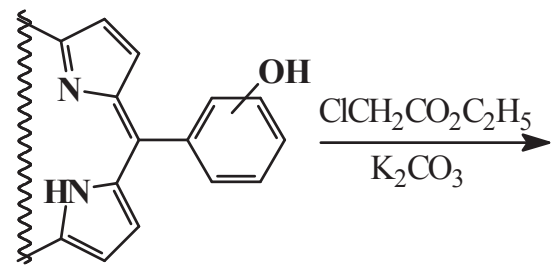

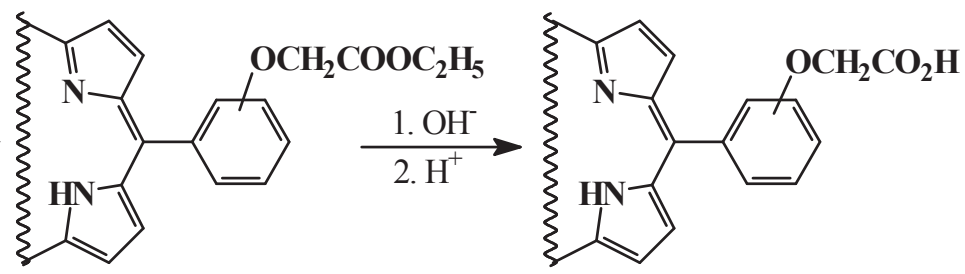

8

Схема 4.<smiles>CCC(N)CC(N)CC(C)N</smiles><smiles></smiles><smiles>CCC(N)CC(N)CC(C)N</smiles>

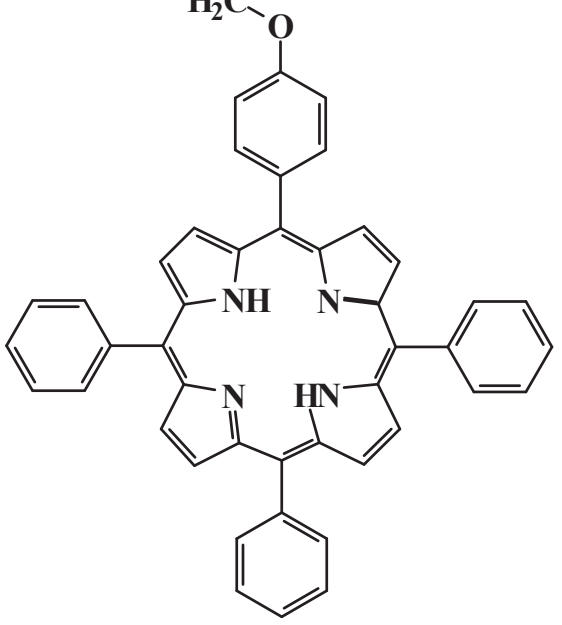

Схема 5. 
билизатов. Они легко закрепляются на соответствующих полимерах-носителях путем ковалентной или ионной иммобилизации. Подходящими полимераминосителями для этой группы порфиринов являются полимерные спирты, полиамины, причем на последних тетра(карбэтоксиметиленоксифенил)порфирины могут быть закреплены как ковалентно с образованием амидной связи, так и посредством ионного связывания (Схема 5).

Алкилирование оксифенилпорфиринов аллил- или пропаргилбромидом позволяет получить порфирины, которые могут выступать в качестве сомономеров в реакции сополимеризации с мономерами непорфириновой природы, такими как метилметакрилат, стирол, акриламид, винилацетат и др. (Схема 6).

Выбор сомономера позволяет получать порфиринполимеры с заданными физико-химическими свойствами, прежде всего растворимостью. Так сополимеры мезо-аллилоксифенилпорфина 10 с метилметакрилатом, полученные методом радикальной сополимеризации в растворе в присутствии пероксида бензоила (Схема 7), хорошо растворяются в ароматических растворителях, и хлороформе, в то время как сополимеры этого порфирина с винилпирролидоном растворимы в воде.

Для создания моделей биологически активных систем большое значение имеет синтез и изучение порфиринов имеющих на периферии молекулы активные функциональные группы способные взаимодействовать с реакционным центром порфиринового макроцикла.

Синтез таких соединений, основанный на модификации природных порфиринов, довольно сложен и включает большое число стадий. Связи, образуемые после «привязки» остатков с активными группами, не очень прочные (в основном они амидные или сложноэфирные). Для синтеза подобных соединений интересно использовать синтетические мезооксифенилпорфирины, которые, как отмечалось выше легко вступают в реакцию алкилирования с галогеналканами и способны образовывать соединения с устойчивыми простыми эфирными связями.

Как правило, количество активных групп на одну порфириновую молекулу редко превышает одну или две, поэтому наиболее подходящими мезооксифенилпорфиринами для этих целей являются монооксифенилпорфирины: оксифенилтриарилпорфирины, которые достаточно легко получить конденсацией пиррола со смесью оксибензальдегида и бензальдегида или более близкие к природным мезо-оксифенил- $\beta$ алкилпорфирины. С помощью реакции алкилирования мезо-оксифенилпорфиринов был осуществлен синтез серии порфиринов с активными группами. ${ }^{[29,30]}$ Обобщенная схема синтеза представлена на Схеме 8.

Таким образом, «привязка» остатков с активными группами к порфирину может проводиться двумя путями: алкилированием оксифенилпорфи-

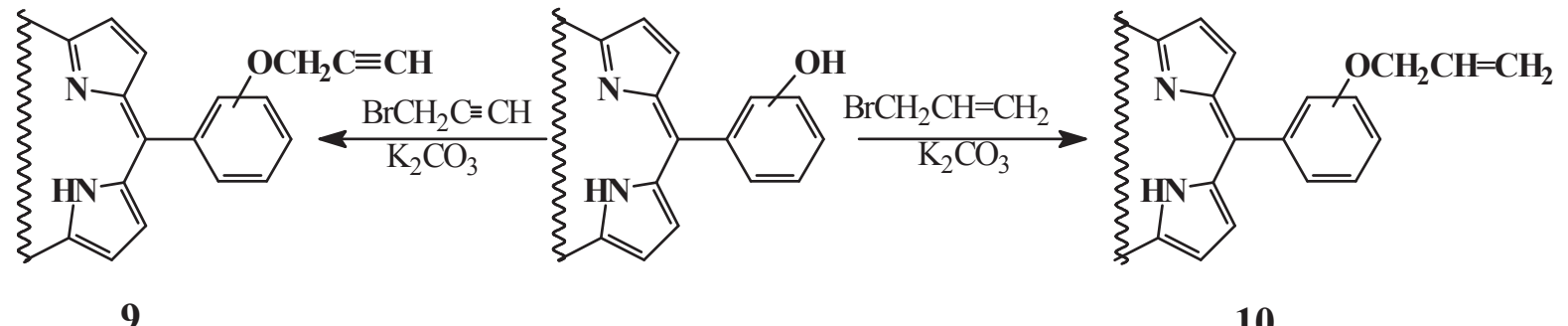

Схема 6.
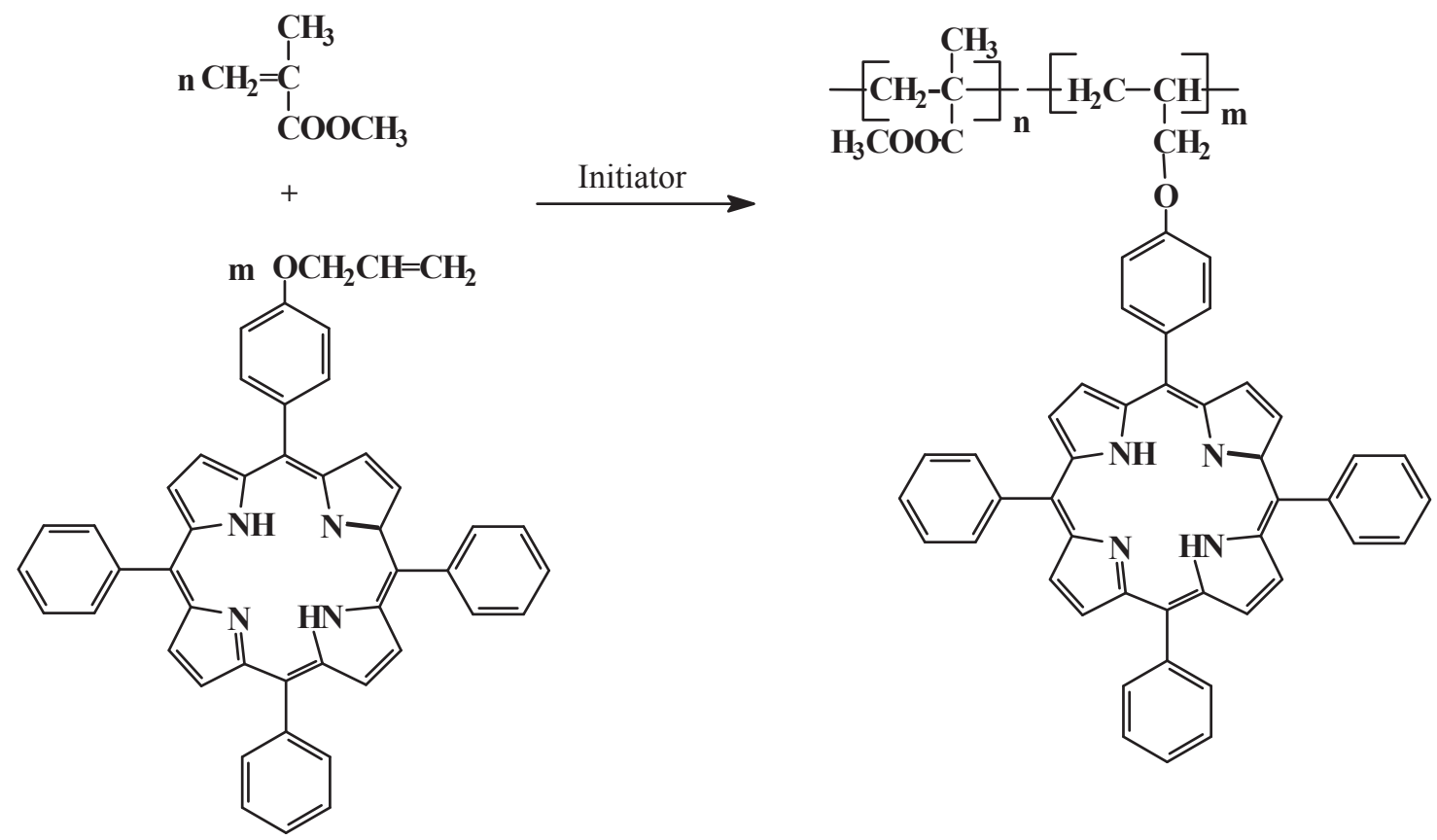

Схема 7. 


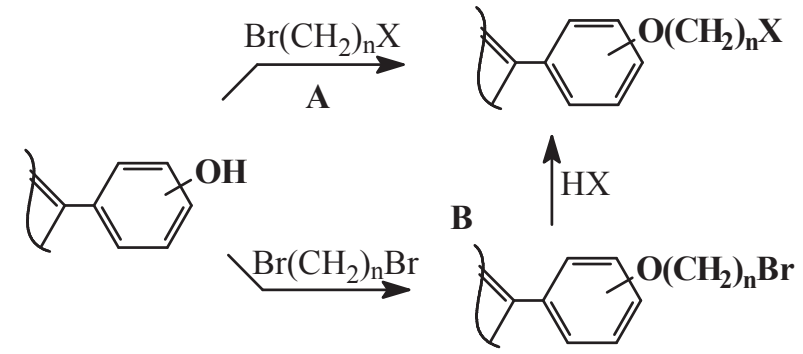

Схема 8.

рина галогеналканом с активной группой (путь А), или предварительным алкилированием оксипорфирина избытком $\alpha, \omega$-дибромалкана с образованием  взаимодействием в аналогичных условиях с соединением, имеющим активную группу (путь В). Изменяя длину алкильной цепи в углеводородном спейсере и его положение в фенильном фрагменте, можно добиться заранее заданного взаимного расположения порфиринового макроцикла и активной группы.

Путь А предпочтительнее, так как короче и дает более высокий выход целевого продукта (в 2,5 раза), Однако не всегда можно получить и очистить галогеналкан, имеющий активную функциональную группу. В связи с этим, в основном, используется путь В. ${ }^{[25,28]}$

Удобными синтонами порфиринполимеров являются аминофенилпорфирины, которые легко закрепляются на различных полимерах-носителях как путем ковалентного связывания, так и ионного. В качестве наиболее удобных полимеров-носителей для них могут быть выбраны полимерные кислоты, полимерные спирты или сополимеры, имеющие свободные карбоксильные или гидроксильные группы.

Однако аминофенилпорфирины прямым методом конденсации аминоальдегида с пирролом получить практически невозможно, т.к. аминобензальдегиды очень неустойчивы. В связи с этим в настоящее время получение аминофенилпорфиринов проводится восстановлением соответствующих нитрофенилпорфиринов (Схема 9), которые получаются с достаточно высокими выходами конденсацией нитробензальдегидов с пирролом и его производными. В настоящее время в качестве единственного восстановителя в данной реакции используется двухлористое олово в соляной кислоте, или в полярных растворителях с ее добавкой. Данный метод, предложенный Колманом, ${ }^{[31]}$ нашел широкое применение.

Для тетра(нитрофенил)порфиринов восстановление проводится при 1,5-кратном избытке дигидрата двухлористого олова в концентрированной соляной

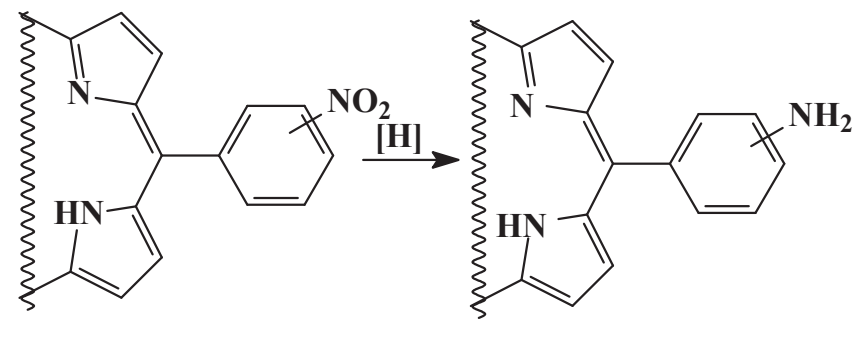

Схема 9.

кислоте при температуре $70-80^{\circ} \mathrm{C}$, что позволяет получить почти количественный выход тетра(аминофенил)порфиринов. ${ }^{[32-33]}$ Моно- и дизамещенные нитрофенилпорфирины требуют более мягких условий восстановления, поэтому в данном случае реакцию восстановления проводят при комнатной температуре ${ }^{[34-35]}$ и в среде метанола, который переводит получаемые аминофенилпорфирины в раствор и способствует полному восстановлению исходных нитрофенилпорфиринов. Недавно был предложен более удобный метод восстановления с использованием в качестве восстановителя гидразин гидрата при катализе палладием на угле в смеси бензол-метанол, что позволяет избежать трудоемкого отделения неорганических солей от аминофенилпорфирина. ${ }^{[36]}$

Для иммобилизации аминопорфиринов на гидроксилсодержащие полимеры-носители (сополимеры винилового или аллилового спиртов, эфиры целлюлозы) целесообразно использовать метод закрепления порфирина на эпоксиактивированный полимер, как описано выше. Следует заметить, что порфирины, содержащие амино-группы в макрогетероцикле наиболее легко вступают во взаимодействие с эпоксидным циклом. ${ }^{[37,38]}$

Предложенным методом получены иммобилизаты как безметальных порфиринов, например 5-(4'-аминофенил)-2,3,7,8,12,18-гексаметил-13,17-дибутилпорфина, так и их металлокомплексов на сополимере стирола с аллиловым спиртом. Причем иммобилизаты $\mathrm{Zn}^{\mathrm{II}}, \mathrm{Cu}^{\mathrm{II}}$, $\mathrm{Co}^{\mathrm{II}}, \mathrm{Ni}^{\mathrm{II}}$ и $\mathrm{Mn}^{\mathrm{III}}$ металлокомплексов порфиринов могут быть получены как путем иммобилизации непосредственно металлопорфиринов, так и в процессе комплексообразования безметальных иммобилизатов с солями металлов в растворах. Иммобилизаты $\mathrm{Co}^{\text {II- }}$ и $\mathrm{Ni}^{\mathrm{II}}$-комплексов аминофенилзамещенных порфинов проявили высокую каталитическую активность в реакции эпоксидирования стирола молекулярным кислородом в ацетонитриле. ${ }^{[23,24]}$

Аминофенилпорфирины легко ацилируются хлорангидридами кислот, ${ }^{[39-41]}$ давая ациламинопроизвод-

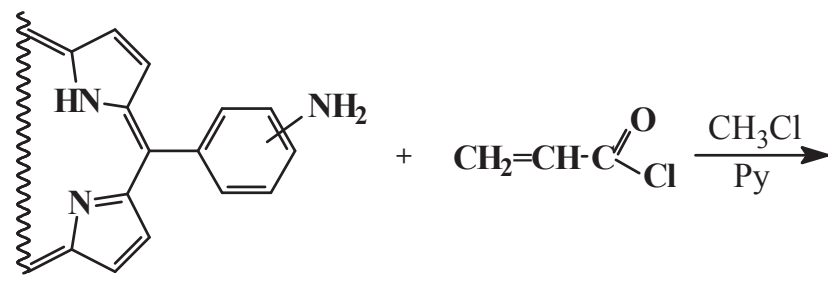

Схема 10

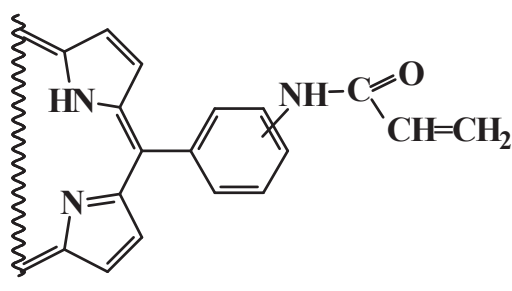

11 


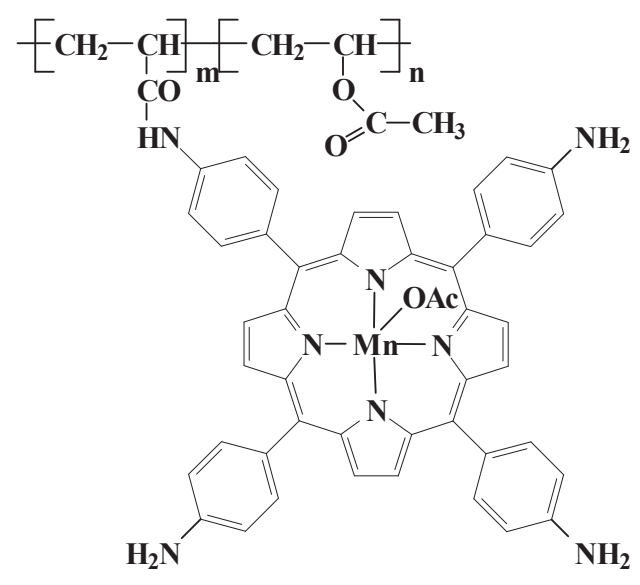

12

ные 11, например, акриловой кислоты, которые могут использоваться в качестве сомономеров вместе с другими традиционными виниловыми мономерами для получения порфиринсодержащих полимеров с заданным содержанием тетрапиррольных соединений в боковой цепи макромолекулы. С целью получения порфириновых мономеров проведено ацилирование ряда мезо-аминофенилпорфиринов хлорангидридом акриловой кислоты в условиях реакции Айнхорна (Схема 10). Реакция проводилась в хлороформе, в качестве основного катализатора использовался пиридин. ${ }^{[39-41]}$

Методом радикальной сополимеризации в растворе ДМФА ацилированного хлорангидридом акриловой кислоты ацетата марганец(III)-тетра(n-аминофенил)порфирина с метакрилатом или с 4-винилпиридином и метакрилатом получены двойные 12 и тройные 13 порфиринсодержащие сополимеры соответственно. [42] Показано, что каталитическая активность иммобилизата 12 в сравнении с мономерным металлопорфирином в реакции окисления холестерина молекулярным кислородом существенно выше. При этом отмечено, что введение объемистых боковых групп в полимер, как пиридильный остаток в 13, снижает каталитическую активность полимерного металлопорфирина, что, вероятно, связано с экранированием реакционных центров. Величина удельной каталитической активности зависит от сочетания гидрофильности и гидрофобно-

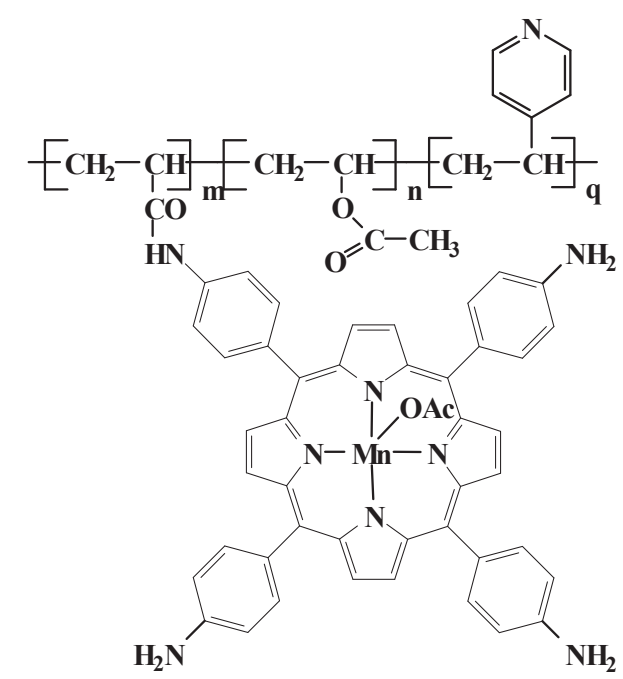

13

сти фрагментов макромолекулярного катализатора и содержания металлопорфирина в нем.

С целью получения водорастворимых порфиринсодержащих полимеров методом сополимеризации $\mathrm{N}$-изопропилакриламида с 5-(4-акриламидофенил)10,15,20-трифенилпорфирином и 5-(4-акрилоксифенил)10,15,20-трифенилпорфирином получены модифицированные поли(N-изопропилакриламиды). ${ }^{[43-46]}$ «Спектральными методами показано, что при использовании в качестве инициатора сополимеризации азо-бис-изобутиронитрила часть порфириновых хромофоров превращается в хлориновые. ${ }^{[44]}$ В связи с этим для сохранения структуры и свойств тетрапиррольного макрогетероцикла выбор метода введения порфирина в полимер имеет важное значение. ${ }^{[45]}$

Реакция сополимеризации синтетических мезоаллилоксифенилпорфинов и мезо-акриламидофенилорфиринов с виниловыми сомономерами протекает достаточно легко. Это, прежде всего, обусловлено удаленностью винильной группы от макрогетероцикла. Однако природные мономеры также могут вступать в реакции сополимеризации и давать порфиринполимеры, в которых тетрапиррольный макрогетероцикл разделен с полимером-носителем очень коротким спейсером. Авторами ${ }^{[47]}$ разработана методика синтеза сополимеров метилфеофорбида $a$ и метилметакрилата в тетрагидрофуране в присутствии инициатора ради-<smiles>C=C(C)C(=O)OC</smiles>

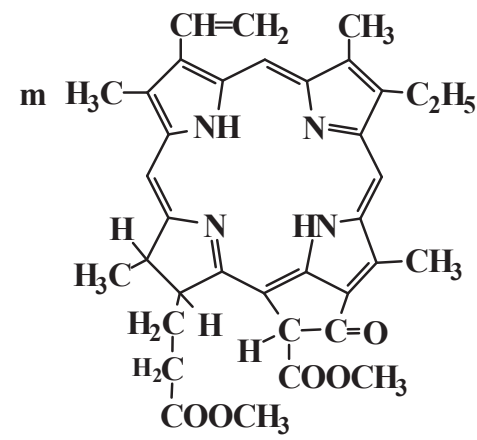

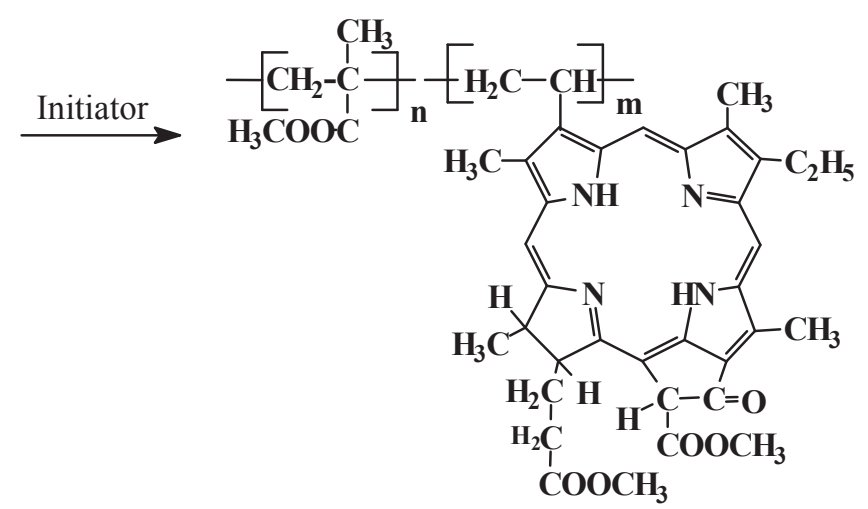

Схема 11. 
кальной полимеризации - динитрила азобисизомасляной кислоты (Схема 11). В результате были получены статистические сополимеры разного состава, содержание порфирина в которых достигает 9 масс \%. Структура полученного порфиринполимера отвечает модели ППИ, представленной на Рисунке 1. Несмотря на существенное влияние на макрогетероцикл полимера метилфеофорбид $а$ сохраняет свои спектральные и координационные свойства.

Удобными молекулярными синтонами, которые позволяют конструировать водорастворимые порфиринполимеры, являются формилпроизводные как природных, (хлорофилл $b$ и его производные) так и синтетических порфиринов. Формилпроизводные мезофенилпорфиринов часто служат основой для дальнейшего молекулярного дизайна в области химии порфиринов с целью получения более сложных молекул с заранее заданными физико-химическими свойствами - стерически затрудненных, ковалентно связанных, димерных и полимерных порфиринов.

Как правило, формил-мезо-фенилпорфирины получают формилированием металлокомплексов мезо-фенилпорфиринов. ${ }^{[48]}$ Одной из наиболее известных и изученных реакцией в области химии порфиринов является формилирование металлокомплексов мезо-тетрафенилпорфиринов по Вильсмайеру. В случае свободного основания тетрафенилпорфина альдегидную группу непосредственно ввести не удается. Напротив, металлокомплексы мезотетрафенилпорфиринов легко формилируются по Вильсмайеру в свободные $\beta$-положения до соответствующих $\beta$-формилпорфиринов 14 (Схема 12). ${ }^{[49,50]}$
Скорость реакции и выход конечного продукта сильно зависят от природы центрального иона металла. Легкость формилирования уменьшается с ростом его электроотрицательности. Лучше всего формилируются комплексы мезо-тетрафенилпорфиринов с $\mathrm{Al}^{\mathrm{III}}, \mathrm{Co}^{\mathrm{III}}$ и $\mathrm{Cr}^{\text {III }}$, что объясняется увеличением реакционной способности, вызванного формированием анионных комплексов ([M"II (TPP) $\left.\mathrm{X}_{2}\right], \mathrm{X}=\mathrm{Cl}$ или $\left.\mathrm{PO}_{2} \mathrm{Cl}_{2}\right)$ в присутствии реактива Вильсмайера.

Г.В. Пономареву удалось значительно улучшить методику получения безметального $\beta$-формил-мезотетрафенилпорфина 14 (M=2H). ${ }^{[50]}$ Он показал, что в отличие от $\mathrm{Cu}, \mathrm{Ni}$ и $\mathrm{Fe}$ комплексов $14(\mathrm{M}=\mathrm{Cu}, \mathrm{Ni}, \mathrm{FeCl})$, неустойчивых к действию серной кислоты, при обработке СоТРР реактивом Вильсмайера можно выделить устойчивое соединение со структурой “фосфорного комплекса", которое легко деметаллируется до иминиевой соли, обработка водным раствором ацетата натрия которой дает $14(\mathrm{M}=2 \mathrm{H})$ с выходом до 65\%. Недостатком этого метода является использование высокореакционоспособного кобольтового комплекса тетрафенилпорфина и, вследствие этого, необходимость тщательного контроля за условиями реакции.

Дальнейшее развитие метод синтеза безметальных $\beta$-формил-мезо-тетрафенилпорфиринов получил в работе, ${ }^{[51]}$ в которой авторы получали подобную иминиевую соль из доступного медного комплекса $\beta$-формилмезо-тетрафенилпорфина $14(\mathrm{M}=\mathrm{Cu})$ и перхлората пиперидина в хлороформе. Деметаллирование $14(\mathrm{M}=\mathrm{Cu})$ с последующим гидролизом иминиевой соли приводит к безметальному $\beta$-формилтетрафенилпорфину 14 $(\mathrm{M}=2 \mathrm{H})$ с выходом 77\%. Наряду с доступностью исход-

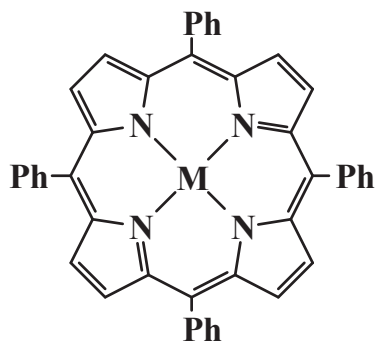

Схема 12.

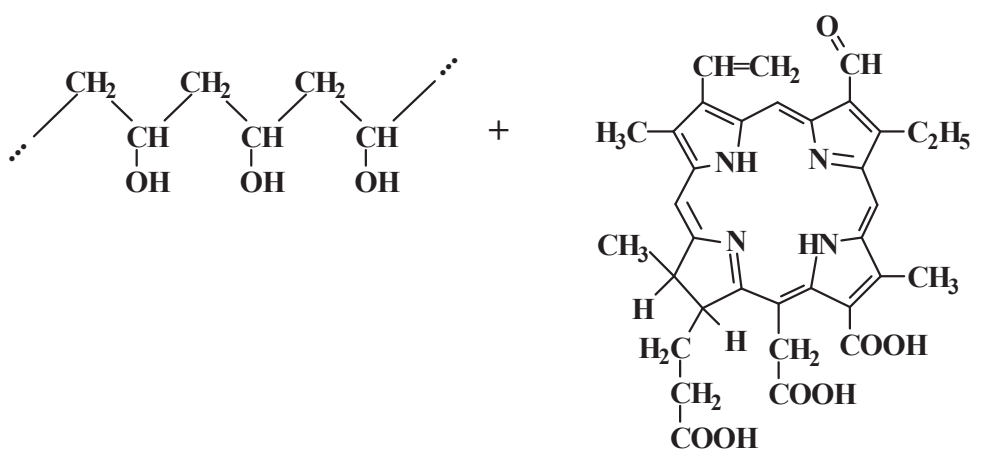

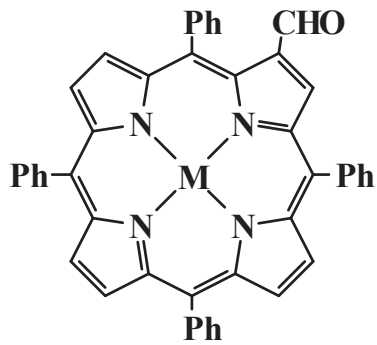

14

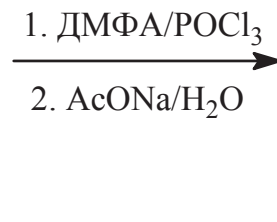

h 
<smiles>CCC(O)CC(O)CC(C)O</smiles>

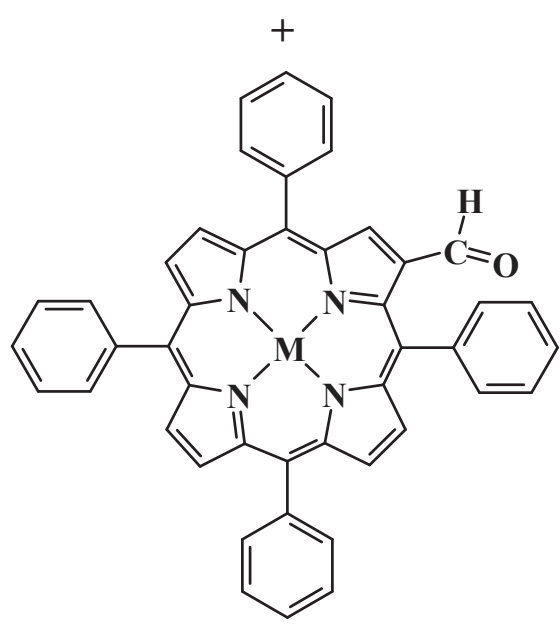

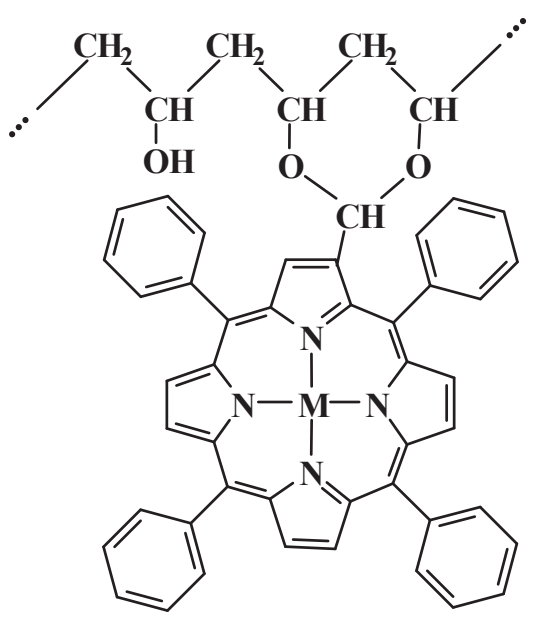

Схема 14.

ного медного комплекса тетрафенилпорфина и высоким выходом продукта реакции авторы работы ${ }^{[5]]}$ отмечают высокую воспроизводимость данного метода.

Впервые реакция закрепления формилпроизводных порфиринов на поливиниловом спирте была разработана на примере природных порфиринов: группы хлорофилла $b,{ }^{[2,53]}$ имеющих формильную группу в положении 3 макрогетероцикла порфирина. Ковалентная иммобилизация феофитина $b$, родина $g_{7}$ и их металлокомплексов на поливиниловый спирт проводилась реакцией ацеталирования, катализируемой минеральными кислотами (Схема 13).

Реакция протекает в гомогенных условиях в среде ДМФА, ДМСО или уксусной кислоты и в зависимости от условий ее проведения получаются водорастворимые, органорастворимые или сшитые иммобилизаты. Мольная степень иммобилизации порфирина определяется главным образом степенью полидисперсности поливинилового спирта.

Более стабильные комплексы $\beta$-формил-мезотетрафенилпорфина позволили расширить круг растворителей, используемых в качестве реакционной среды, и подобрать условия, сохраняющие структуру исходного полимера-носителя. Проведение реакции ацеталирования поливинилового спирта $\beta$-формил-мезотетрафенилпорфина (Схема 14) в этиленгликоле или смешанном растворителе этиленгликоль-хлороформ позволяет получить водорастворимые иммобилизаты, ${ }^{[54]}$ которые обладают хорошими пленкообразующими свойствами.

Методы иммобилизации порфиринов на полимерноситель в объеме полимера с успехом могут быть использованы для модификации поверхности полимерных материалов (пленок, нитей, гранул) с целью придания им специфических свойств. Для этого достаточно создать на поверхности полимерного материала активные функциональные группы, способные взаимодействовать с порфирином. Эффективным методом моди- фикации является обработка полимеров в неравновесной газоразрядной плазме, которая приводит к образованию в тонком поверхностном слое полимера требуемых функциональных групп без изменения объемных свойств материала. ${ }^{[55-58]}$ Окисление поверхности пленок полипропилена в кислородной плазме пониженного давления или в системе «плазма атмосферного давления - раствор электролита» позволяет иммобилизовать порфирины с аминогруппами на периферии макрогетероциклических молекул.

Таким образом, успехи препаративной химии тетрапиррольных макрогетероциклических соединений в настоящее время открывают путь к синтезу практически неограниченного количества полимерсвязанных порфиринов. Варьируя свойства молекулярных синтонов порфиринполимеров, можно целенаправленно управлять специальными свойствами новых функциональных материалов. Объединяя специфические свойства полимеров и порфиринов, может быть выявлен целый ряд совершенно новых направлений в их использовании. Они представляют несомненный интерес для решения многих задач биотехнологии, биологии, фармакологии и медицины. Новые материалы на основе полимерсвязанных порфиринов и их металлокомплексов могут проявить совершенно необычные свойства, в частности благодаря введению металла в макромолекулу модифицированного полимера, что, несомненно, откроет новые перспективы их использования.

Благодарность. Работа выполнена при финансовой поддержке грантов РФФИ 07-03-00818-а и 09-03-00927 а.

\section{Список литературы}

\section{References}

1. Berezin B.D. Coordination Compounds of Porphyrins and Phthalocyanine. New Jork-Toronto: J. Wiley, 1981, 286 p. 
2. Porfiriny: Struktura, Svoistva, Sintez [Porphyrins: Structure, Properties, Synthesis] (Enikolopyan N.S., Ed.) Moskva: Nauka, 1985, 333 p. (in Russ).

3. Porfiriny: Spektroskopiya, Elektrokhimiya, Primenenie [Porphyrins: Spectroscopy, Electrochemistry, Application] (Enikolopyan N.S., Ed.), Moskva: Nauka, 1987, 384 p. (in Russ).

4. Berezin B.D., Enikolopyan N.S. Metalloporfiriny [Metalloporphyrins] Moskva: Nauka, 1988, 159 p. (in Russ).

5. Berezin B.D., Rumyantseva S.V., Moryganov A.P., Berezin M.B. Uspekhi Khimii 2004, 73, 197-207 (in Russ).

6. Koifman O.I., Ageeva T.A. Vysokomol. Soedin., Ser. C 2004, 46, 2187-2215 (in Russ) .

7. Koifman O.I., Ageeva T.A. Porfirinpolimery [Porphyrinpolymers] Moskva: IFML, 2006, 194 p. (in Russ).

8. Ageeva T.A., Nikolaeva O.I., Koifman O.I. Izv. Vyssh. Ucheb. Zaved., Khim. Khim. Tekhnol. 2004, 47(5), 91-101 (in Russ).

9. Mitasova Yu.V., Kuznetsov R.E., Balantseva E.V., Ageeva T.A., Koifman O.I. Izv. Vyssh. Ucheb. Zaved., Khim. Khim. Tekhnol. 2008, 51(1), 74-77 (in Russ).

10. Syrbu S.A., Ageeva T.A., Semeikin A.S., Koifman O.I. Izv. Ross. Akad. Nauk, Ser. Khim. 2007, 56, $680-703$ (in Russ).

11. Mikhailov O.V. Reaktsii Kompleksoobrasovaniya $v$ ZhelatinImmobolizovannykh Matrichnykh Implantantakh [The Complexation Reactions in Gelatin-Immobilized Matrix Implantates] Kazan': Fan, 2002, 228 p. (in Russ).

12. Mikhailov O.V., Kazumova M.A., Chachkov D.V. Macroheterocycles 2008, 1, 90-97.

13. Kolodina E.A., Lubimova T.V., Syrbu S.A., Semeikin A.S. Macroheterocycles 2009, 2, 33-41.

14. Syrbu S.A., Semeikin A.S., Koifman O.I., Berezin B.D., Zhamkochan G.A. USSR Patent № 1267759.

15. Syrbu S.A., Semeikin A.S., Koifman O.I., Berezin B.D. Org. Poluprovod. Materialy 1986, 9, 81-85 (in Russ).

16. Little R.G., Anton J.A., Loach P.A., Ibers J.A. J. Heterocycl. Chem. 1975, 12, 342-349.

17. Semeikin A.S., Koifman O.I., Berezin B.D., Syrbu S.A. Khim. Geterotsikl. Soedin. 1983, 1359-1361 (in Russ)

18. Matile S., Hansen T., Storster A., Wogjon W.D. Helv. Chim. Acta. 1994, 77, 1087-1098.

19. Momenteau M., Le Bras F., Looch B. Tetrahedron Lett. 1994, 35, 3289-3292.

20. Syrbu S.A., Semeikin A.S. Zh. Org. Khim. 1999, 35, 12621265 (in Russ).

21. Semeikin A.S., Koifman O.I., Berezin B.D. Izv. Vyssh. Ucheb. Zaved., Khim. Khim. Tekhnol. 1981, 24, 566-569 (in Russ).

22. Syrbu S.A., Semeikin A.S., Berezin B.D. Khim. Geterotsikl. Soedin. 1990, 1507-1509 (in Russ).

23. Nikolaeva O.I., Kurek S.S., Ageeva T.A., Koifman O.I. Izv. Vyssh. Ucheb. Zaved., Khim. Khim. Tekhnol. 2004, 47(2), 146149 (in Russ).

24. Nikolaeva O.I., Kurek S.S., Ageeva T.A., Semeikin A.S., Koifman O.I. J. Porphyrins Phthalocyanines 2004, 8, 587.

25. Little R.G. J. Heterocycl. Chem. 1978, 15, 203-208.

26. Berezin B.D., Semeikin A.S., Nikitina G.E., Koifman Z.C., Koifman O.I. Zh. Fiz. Khim. 1985, 59, $2226-2229$ (in Russ).

27. Semeikin A.S., Koifman O.I., Nikitina G.E., Berezin B.D., Zh. Org. Khim. 1984, 54, 1599-1603 (in Russ).

28. Syrbu S.A., Semeikin A.S., Berezin B.D., Koifman O.I. Khim. Geterotsikl. Soedin. 1989, 1373-1377 (in Russ).

29. Lyubimtsev A., Syrbu S.A., Vagin S.I., Hanack M. Eur. J. Org. Chem. 2007, 2000-2005.

30. Syrbu S.A., Semeikin A.S., Koifman O.I. Izv. Vyssh. Ucheb. Zaved., Khim. Khim. Tekhnol. 2004, 47(5), 46-55 (in Russ).

31. Collman J.P., Gagne R.R., Halbert T.R., Marchon J.C., Reed C.A. J. Amer. Chem. Soc. 1973, 95, 7868-7870.
32. Semeikin A.S., Koifman O.I., Berezin B.D. Khim. Geterotsikl. Soedin. 1982, 1354-1355 (in Russ).

33. Semeikin A.S., Koifman O.I., Berezin B.D. Izv. Vyssh. Ucheb. Zaved., Khim. Khim. Tekhnol. 1985, 28(11), 47-51 (in Russ).

34. Gribkova S.E., Luzgina V.N., Evstigneeva R.P. Zh. Org. Khim. 1993, 29, 758-762 (in Russ).

35. Palka A., Czuchajowski L. Chem. Lett. 1994, 547-550.

36. Syrbu S.A., Glazunov A.V., Semeikin A.S. Izv. Vyssh. Ucheb. Zaved., Khim. Khim. Tekhnol. 2006, 49(4), 122-123 (in Russ)

37. Belykh D.V., Nikolaeva O.I., Ageeva T.A., Vershinina I.A., Karmanova L.P., Kuchin A.V. Izv. Vyssh. Ucheb. Zaved., Khim. Khim. Tekhnol. 2004, 47(5), 102-106 (in Russ).

38. Ageeva T.A., Nikolaeva O.N., Krivyh E.S., Mitasova Yu.V., Koifman O.I. J. Porphyrins Phtalocyanines 2006, 10, 526.

39. Syrbu S.A., Semeikin A.S., Korzhenevsky A.B., Koifman O.I. Patent of Russian Federation № 2277557. Bull. Izobr. №16 (10.06.2006) (in Russ).

40. Syrbu S.A., Semeikin A.S., Korzhenevsky A.B., Koifman O.I. Patent of Russian Federation № 2281304. Bull. Izobr. №22 (10.08.2006) (in Russ).

41. Syrbu S.A., Semeikin A.S., Korzhenevsky A.B., Koifman O.I., Buryaeva I.V. Patent of Russian Federation № 2281305. Bull. Izobr. №22 (10.08.2006) (in Russ).

42. Solov'yova A.B., Samokhvalova A.I., Lebedeva T.S., Pshezhetskii V.S., Karmilova L.B., Enikolopyan N.C. Dokl. Akad. Nauk SSSR 1986, 290, 1383-1386 (in Russ).

43. Avlasevich Yu.S., Kulinkovich O.G., Knyukshto V.N., Losev A.P., Solov'ev K.N. Vysokomol. Soedin. Ser. A, 1997, 39, 1740-1748 (in Russ).

44. Avlasevich Yu.S., Kulinkovich O.G., Knyukshto V.N., Solov'ev K.N. Zh. Prikl. Spektrosk. 1999, 66, 538-541 (in Russ).

45. Avlasevich Yu.S., Knyukshto V.N., Solov'ev K.N. Dokl. Akad. Nauk Belarusi 2000, 44, 56-59 (in Russ).

46. Avlasevich Yu.S., Chevtchouk T.A., Knyukshto V.N., Kulinkovich O.G., Solov'ev K.N. J. Porphyrins Phthalocyanines 2000, 4, 579-586.

47. Nikolaeva O.I., Ageeva T.A., Koifman O.I. J. Porphyrins Phthalocyanines 2008, 12, 437.

48. Ishkov Yu.V., Vodzinskii S.V., Zhilina Z.I. In Uspekhi Khimii Pofirinov [Advances in Porphyrin Chemistry] (Golubchikov O.A., Ed.) Vol. 5, St. Petersburg, NII Khimii SPbGU, 2007, 50-71 (in Russ).

49. Callot H.J. Tetrahedron 1973, 29, 899-901.

50. Ponomarev G.V., Maravin G.B. Khim. Geterotsikl. Soedin. 1982, 59-64 (in Russ).

51. Ishkov Yu.V., Zhilina Z.I., Grushevaya Zh.V. Zh. Org. Khim. 1993, 29, 2270-2274 (in Russ).

52. Govorov A.G., Korzhenevsky A.B., Koifman O.I. Izv. Vyssh. Ucheb. Zaved., Khimija i Khim. Tekhnol. 1993, 36(3), 75-81 (in Russ).

53. Govorov A.G., Korzhenevsky A.B., Koifman O.I. Izv. Vyssh. Ucheb. Zaved., Khim. Khim. Tekhnol. 1993, 36(9), 86-90 (in Russ).

54. Ageeva T.A., Alopina E.V., Kolodina E.A., Klein E.V., Koifman O.I. J. Porphyrins Phthalocyanines 2008, 12, 436.

55. Golubchikov O.A., Ageeva T.A., Titov V.A. Ross. Khim. Zh. im. D.I. Mendeleeva 2004, 48, 166-172 (in Russ).

56. Ageeva T.A., Vershinina I.A., Gornukhina O.V., Shikova T.G., Titov V.A., Golubchikov O.A. J. Porphyrins Phtalocyanines 2004, 8, 588.

57. Choi H.S., Rybkin V.V., Titov V.A., Shikova T.G., Ageeva T.A. Surface and Coatings Technology 2006, 200, 4479-4488.

58. Zenkevich E.I., Martin J., von Borczyskowski C., Ageeva T.A., Titov V.A., Knyukshto V.N. Macroheterocycles 2008, 1, 59-67. 